\title{
An echocardiographic study of perimembranous ventricular septal defect with left ventricular to right atrial shunting
}

\author{
MAURICE P LEUNG, C K MOK, * ROXY N S LO, K C LAU \\ From the Departments of Paediatrics and * Surgery, University of Hong Kong, Grantham Hospital, Hong
Kong
}

SUMMARY Twenty nine patients with isolated perimembranous ventricular septal defects were investigated by $M$ mode, cross sectional, and pulsed Doppler echocardiography. Tricuspid valve anomalies were present in all six patients with a left ventricular-right atrial shunt but in only six $(26 \%)$ of 23 patients who had interventricular shunts only. Systolic flutter of the tricuspid valve was shown in five $(83 \%)$ of the six patients with a ventriculoatrial shunt but not in the other patients. Systolic turbulence in both the right ventricle and right atrium was detected by Doppler echocardiography only in patients with ventriculoatrial shunting. A perimembranous ventricular septal defect with left ventricular to right atrial shunt can be diagnosed by its combined M mode, cross sectional, and pulsed Doppler echocardiographic features.

A left ventricular to right atrial shunt is usually not recognised until cardiac catheterisation has been performed. An increase in atrial oxygen saturation when the interatrial septum is intact suggests such a communication. The passage of contrast medium across the ventricular septum with immediate opacification of the dilated right atrium during selective left ventriculography is diagnostic. ${ }^{1}$ Some of the echocardiographic features of ventriculoatrial communications have been described in single case reports. ${ }^{2-7}$ The present study is an attempt to define the $M$ mode, cross sectional, and pulsed Doppler echocardiographic features of perimembranous ventricular septal defects with left ventricular to right atrial shunts.

\section{Patients and methods}

Twenty nine patients with isolated perimembranous ventricular septal defects were studied. Six patients (aged 2 months to 26 years (mean 8 years 1 month)) had both interventricular and ventriculoatrial shunts. Twenty three patients (aged 3 months to 26

Requests for reprints to Dr Maurice P Leung, Department of Paediatrics, Queen Mary Hospital, Pokfulam Road, Hong Kong.

Accepted for publication 20 August 1985 years (mean 4 years 9 months)) had interventricular shunts only. In all patients cardiac catheterisation and cinecardioangiographic examination confirmed these intracardiac anomalies. Echocardiography was performed using the duplex system of the Mark V ATL instrument (MK 600) (Advanced Technology Laboratory, Bellevue, WA 98008) fitted with either a 3 or $5 \mathrm{MHz}$ transducer. Standard views were used to identify the septal defect ${ }^{8}$ and to determine its relation to the tricuspid valve. The presence of tricuspid valve anomalies and $M$ mode echocardiography of the tricuspid valve were recorded.

Left to right shunting in the right ventricle close to the ventricular septal defect, the possibility of tricuspid regurgitation, and direct ventriculoatrial shunting were evaluated by pulsed Doppler echocardiography. The sample volume was initially placed in the right ventricle adjacent to the septal defect and then in the right atrium close to the tricuspid valve. Any Doppler frequency shift indicating turbulent flow was noted. The direction and flow pattern of laminar or disturbed blood flow were displayed graphically. (Aliasing occurred when the turbulent flow exceeded the Nyquist limit of the machine.) Audio signals were also used to assist in the differentiation between laminar and turbulent flow. Simultaneous $M$ mode display was used to determine the position of the sample volume and the elec- 
Table 1 Summary of echocardiographic, cardiac catheterisation, and cineangiographic findings in patients with ventriculoatrial shunt

\begin{tabular}{|c|c|c|c|c|c|c|c|c|c|}
\hline \multirow[t]{2}{*}{ Case } & \multirow[t]{2}{*}{ Sex/age } & \multirow[t]{2}{*}{$V S D$} & \multirow{2}{*}{$\begin{array}{l}\text { Tricuspid valve } \\
\text { anomalies }\end{array}$} & \multirow{2}{*}{$\begin{array}{l}\text { Tricuspid } \\
\text { valve flutter }\end{array}$} & \multicolumn{2}{|c|}{$\begin{array}{l}\text { Systolic } \\
\text { turbulence }\end{array}$} & \multicolumn{2}{|c|}{ Catheterisation findings } & \multirow{2}{*}{$\begin{array}{l}L V \text { angiogram } \\
\text { findings }\end{array}$} \\
\hline & & & & & $R A$ & $\overline{R V}$ & $\begin{array}{l}\text { PA pressure } \\
(\mathrm{mm} \mathrm{Hg})\end{array}$ & $Q P: Q S$ & \\
\hline 1 & $\mathrm{~F} / 5^{1 / 2} \mathrm{yr}$ & Perimembranous & $\begin{array}{l}\text { Adherence of septal } \\
\text { leaflet to VSD margins }\end{array}$ & ++ , systolic & + & + & $\begin{array}{l}37 / 6 \\
\quad(\text { mean } 26)\end{array}$ & $1 \cdot 4: 1$ & $\begin{array}{l}\text { Contrast to both } R A \stackrel{\widetilde{\Phi}}{\text { and } R V} \\
\text { and }\end{array}$ \\
\hline 2 & $M / 2$ month & Perimembranous & $\begin{array}{l}\text { Widened anteromedial } \\
\text { commissure } \\
\text { (thickened, dysplastic } \\
\text { valve at necropsy) }\end{array}$ & 0 & + & + & $\begin{array}{l}55 / 25 \\
\text { (mean 30) }\end{array}$ & $3 \cdot 9: 1$ & Contrast to RA \\
\hline 3 & $\mathrm{M} / 9 \mathrm{yr}$ & Not seen & Thickened septal leaflet & ++ , systolic & + & + & $\begin{array}{l}32 / 11 \\
\quad(\text { mean } 20)\end{array}$ & $1 \cdot 7: 1$ & $\begin{array}{l}\text { Small jet to both } R A \\
\text { and } R V\end{array}$ \\
\hline 4 & $\mathrm{~F} / 7 \mathrm{yr}$ & Perimembranous & $\begin{array}{l}\text { Adherence of septal } \\
\text { leaflet to VSD margins }\end{array}$ & ++ , systolic & + & + & $\begin{array}{l}32 / 10 \\
\text { (mean 20) }\end{array}$ & $2 \cdot 3: 1$ & $\begin{array}{l}\text { Contrast to both RA } \\
\text { and RV }\end{array}$ \\
\hline 5 & F/10 month & Perimembranous & $\begin{array}{l}\text { Pouch like } \\
\text { malformation of } \\
\text { septal leaflet }\end{array}$ & + , systolic & + & + & $\begin{array}{l}24 / 14 \\
\text { (mean 18) }\end{array}$ & $2 \cdot 5: 1$ & $\begin{array}{l}\text { "Aneurysm of } \\
\text { membranous } \\
\text { septum". Contrast } \\
\text { to both RA and RV }\end{array}$ \\
\hline 6 & $\mathrm{~F} / 26 \mathrm{yr}$ & Perimembranous & $\begin{array}{l}\text { Pouch like } \\
\text { malformation of } \\
\text { septal leaflet }\end{array}$ & + , systolic & + & + & $\begin{array}{l}30 / 6 \\
\quad(\text { mean } 16)\end{array}$ & $2: 1$ & $\begin{array}{l}\text { "Aneurysm of } \\
\text { membranous } \\
\text { septum". Contrast } \\
\text { to both RA and RV }\end{array}$ \\
\hline
\end{tabular}

LV, left ventricle; PA, pulmonary artery; RA, right atrium; RV, right ventricle; QP:QS, ratio of pulmonary blood flow to systemic blood flow; VSD, ventricular septal defect.

trocardiogram was used to time the events. When the defect was not clearly visualised, a search was made for systolic turbulence in different parts of the right ventricle by varying the position of the sample volume. Detection of systolic spectral dispersion in the right atrium or ventricle by Doppler technique was accepted as evidence of shunting.

\section{Results}

Table 1 gives the findings in the patients with ventriculoatrial shunting, and Table 2 compares the findings in the two groups.

\section{VENTRICULOATRIAL SHUNTING}

The septal defect was visualised in five of the six patients. Tricuspid valve anomalies were observed in all six patients. A redundant septal leaflet with a

Table 2 A comparison of the echocardiographic features of patients with or without a ventriculoatrial shunt

\begin{tabular}{lll}
\hline Feature & \multicolumn{2}{l}{ No of patients } \\
\cline { 2 - 3 } & $\begin{array}{l}\text { With shunt } \\
(n=6)\end{array}$ & $\begin{array}{l}\text { Without shunt } \\
(n=23)\end{array}$ \\
\hline $\begin{array}{l}\text { VSD visualised by cross } \\
\text { sectional echocardiography }\end{array}$ & 5 & 17 \\
$\begin{array}{c}\text { Presence of tricuspid valve } \\
\text { anomalies }\end{array}$ & 6 & 6 \\
$\begin{array}{c}\text { Presence of tricuspid valve } \\
\text { systolic flutter }\end{array}$ & 5 & 0 \\
$\begin{array}{c}\text { Systolic turbulence detected by } \\
\text { Doppler in right atrium }\end{array}$ & 6 & 0 \\
$\begin{array}{c}\text { Systolic turbulence detected by } \\
\text { Doppler in right ventricle }\end{array}$ & 6 & 23 \\
\hline
\end{tabular}

pouch like malformation in the vicinity of the septal defect (Fig. 1a) was observed in two patients. Adherence of valve tissue to the margins of the septal defect (Fig. 1b and c) was demonstrated in two other patients. Widening of the anteromedial commissure (Fig. 2b and c) was seen in one other patient. In the remaining patient, there was thickening and distortion of the septal leaflet. Systolic flutter of the tricuspid valve leaflet (Fig. 3) was seen in the $M$ mode echocardiograms of five patients. Doppler echocardiography showed systolic turbulence in both right ventricle and right atrium (Fig. 4) in all six patients.

\section{INTERVENTRICULAR SHUNT ALONE}

A septal defect was visualised in $17(74 \%)$ of the 23 patients. Twelve of the defects mainly affected the inlet septum and the remaining five extended to the apical trabecular and outlet region. In two patients, the subcostal four chamber view gave a false impression that the defect extended above the tricuspid valve annulus (a direct ventriculoatrial communication (Fig. 5a)). This was excluded by readjusting the transducer position (Fig. 5b) and by Doppler echocardiography (Fig. 5c). An anomaly of the tricuspid valve was demonstrated in six patients $(26 \%)$. Pouch like malformations with redundancy of the septal leaflet were seen in three patients (Fig. $5 b)$ and adherence of accessory valve tissue to the margins of the defect was seen in the other three. There was no abnormal oscillation of the tricuspid valve in any patient. In all 23 patients Doppler techniques showed systolic turbulence in the right ventricle alone (Fig. 5c). 

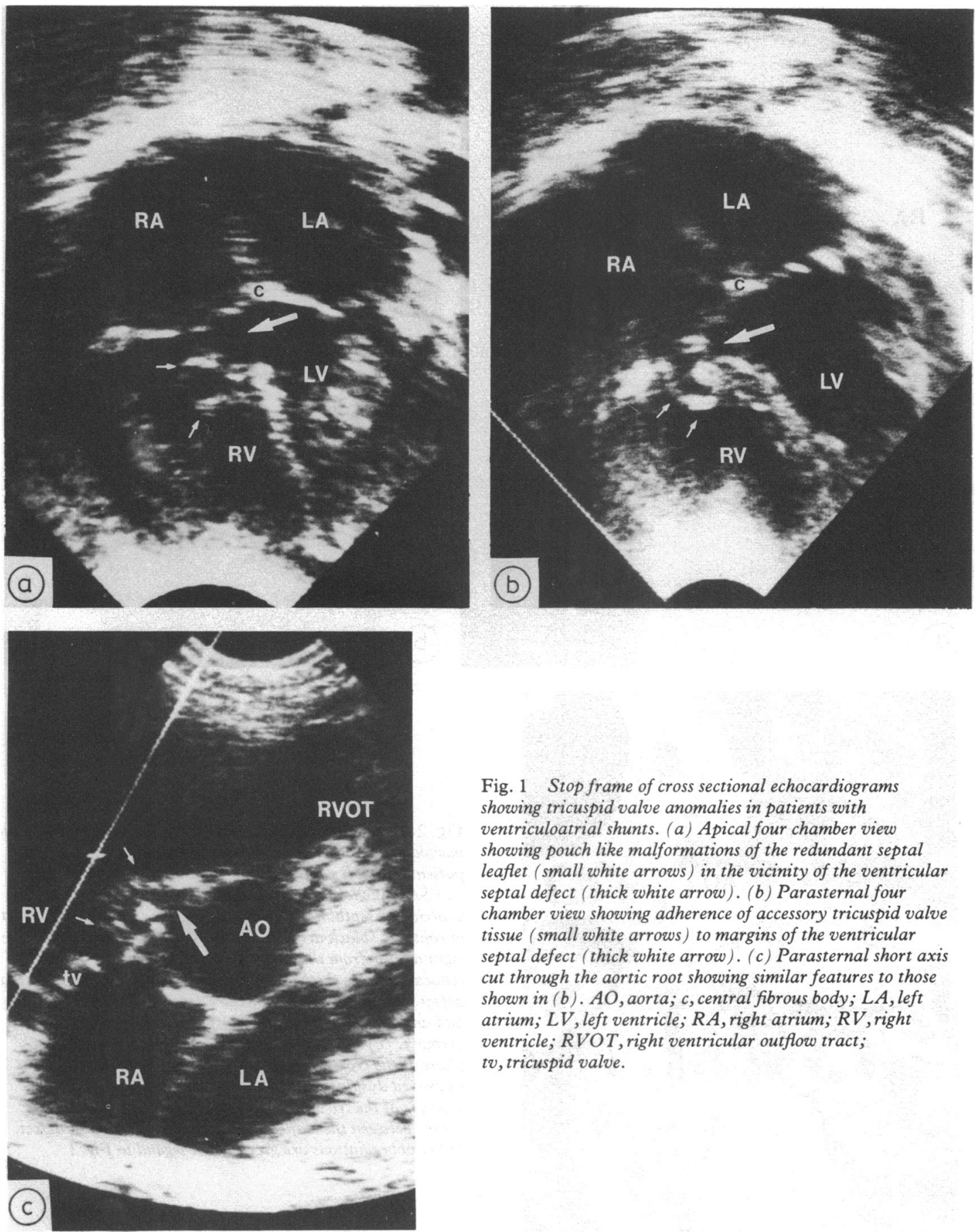

Fig. 1 Stop frame of cross sectional echocardiograms showing tricuspid valve anomalies in patients with ventriculoatrial shunts. (a) Apical four chamber view showing pouch like malformations of the redundant septal leaflet (small white arrows) in the vicinity of the ventricular septal defect (thick white arrow). (b) Parasternal four chamber view showing adherence of accessory tricuspid valve tissue (small white arrows) to margins of the ventricular septal defect (thick white arrow). (c) Parasternal short axis cut through the aortic root showing similar features to those shown in (b). AO, aorta; $c$, central fibrous body; $L A$, left atrium; $L V$, left ventricle; $R A$, right atrium; $R V$, right ventricle; $R V O T$, right ventricular outflow tract; tv, tricuspid valve. 

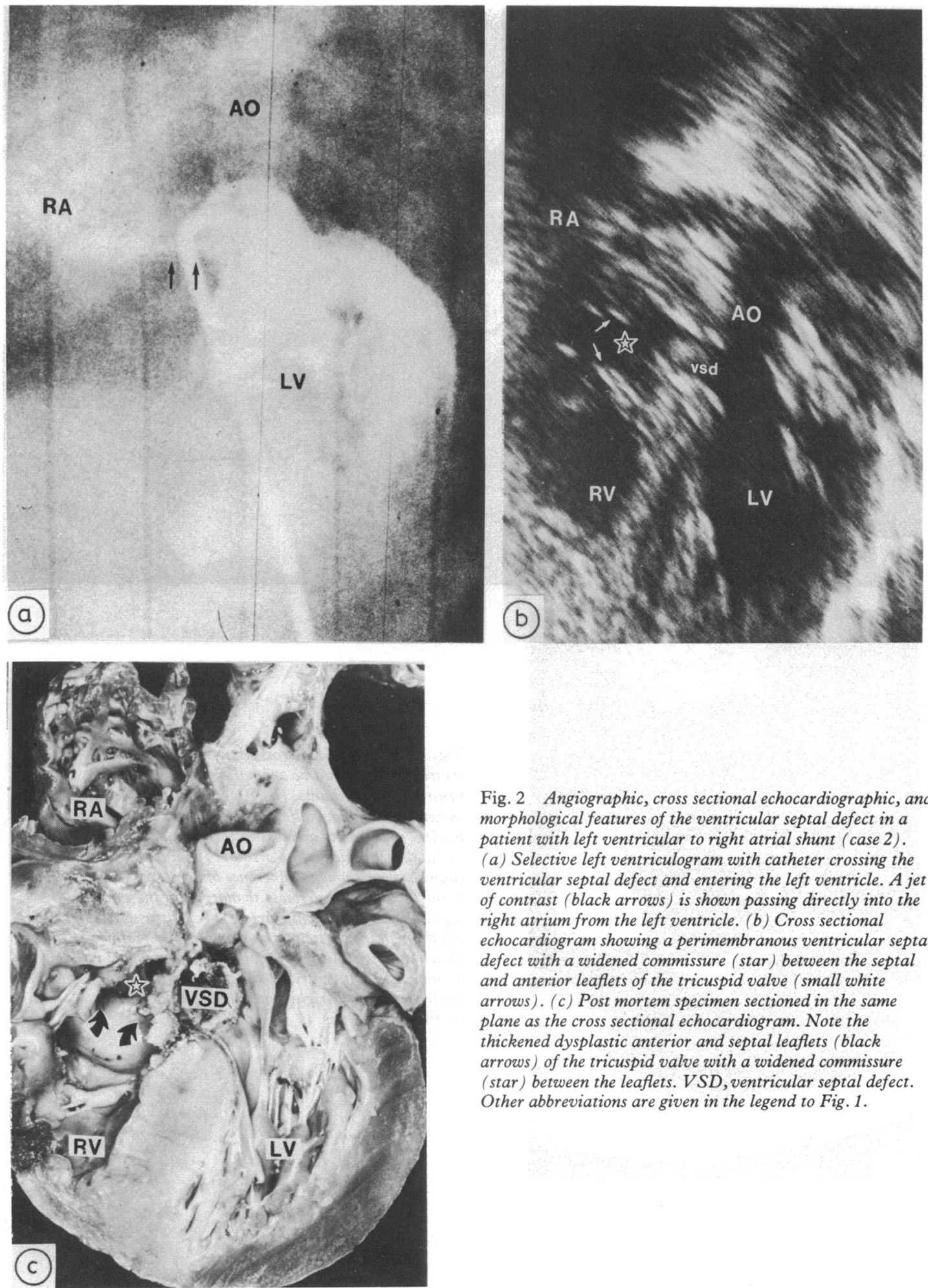

Fig. 2 Angiographic, cross sectional echocardiographic, and morphological features of the ventricular septal defect in a patient with left ventricular to right atrial shunt (case 2). (a) Selective left ventriculogram with catheter crossing the ventricular septal defect and entering the left ventricle. A jet of contrast (black arrows) is shown passing directly into the right atrium from the left ventricle. (b) Cross sectional echocardiogram showing a perimembranous ventricular septal defect with a widened commissure (star) between the septal and anterior leaflets of the tricuspid valve (small white arrows). (c) Post mortem specimen sectioned in the same plane as the cross sectional echocardiogram. Note the thickened dysplastic anterior and septal leaflets (black arrows) of the tricuspid valve with a widened commissure (star) between the leaflets. VSD, ventricular septal defect. Other abbreviations are given in the legend to Fig. 1. 


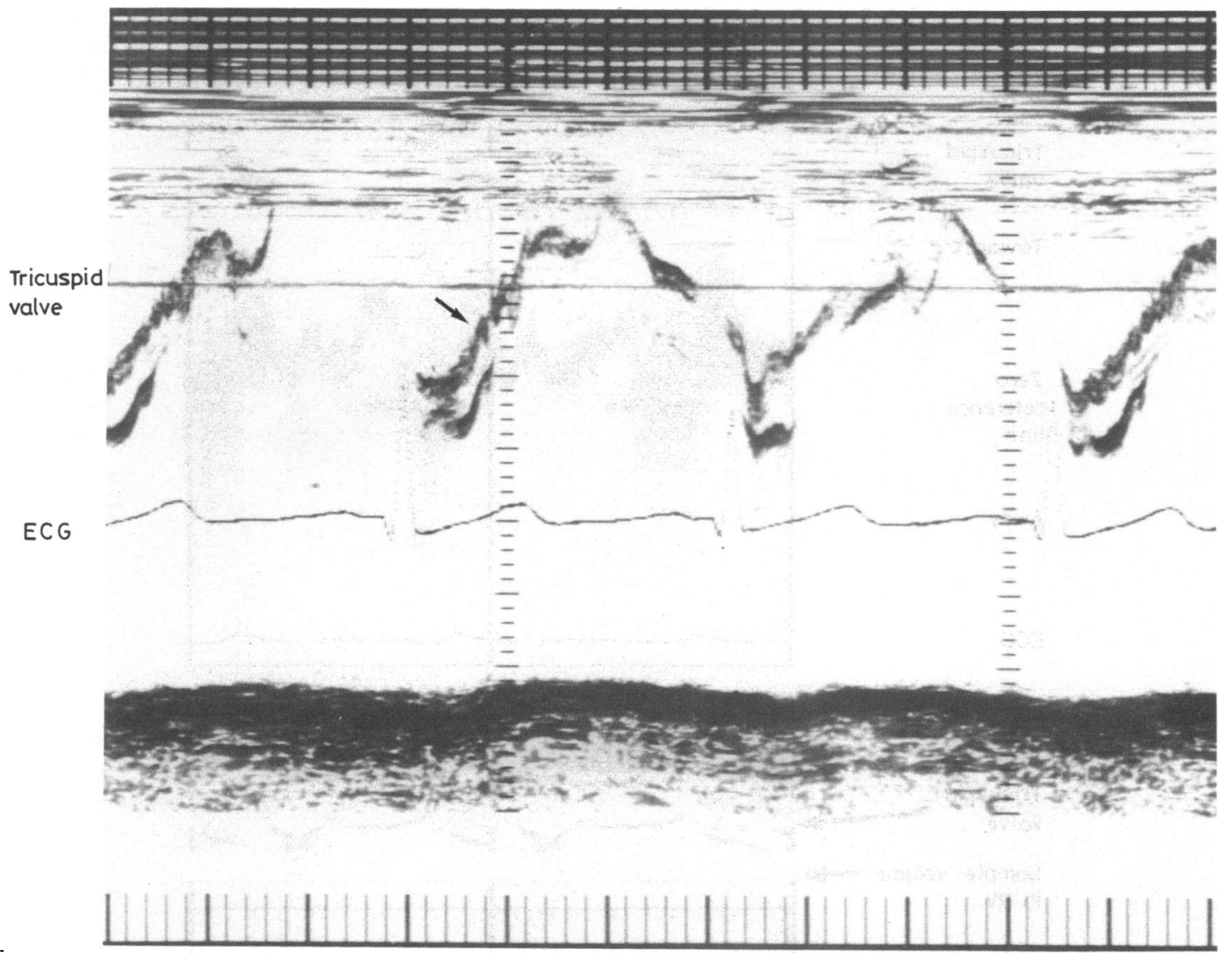

Fig. $3 M$ mode echocardiography of the tricuspid valve showing the high frequency low amplitude systolic flutter (black arrow). ECG, electrocardiogram.

\section{Discussion}

Ventriculoatrial communications are divided into two main groups depending upon whether the septal defect is above or below the level of attachment of the septal leaflet of the tricuspid valve. Occasionally both supravalvar and infravalvar areas are affected. ${ }^{1}$ The cases available for study had the most common type of shunt, namely that associated with a perimembranous ventricular septal defect.

There was no difference in the cross sectional echocardiographic appearance of the defect in the two groups of patients. In some patients with an exclusively ventricular shunt, tilting the transducer slightly more anteriorly than usual in the subcostal four chamber view produced a false image of ventriculoatrial communication. When the transducer is not properly positioned in a patient in whom the tricuspid valve tissue is adherent to the margin of the ventricular septal defect, the upper part of the defect may appear to lie above the level of attachment of the tricuspid valve (Fig. 5a). This impression can be easily corrected by adjustment of the position of the transducer so that the plane passes through the central fibrous body of the heart in the apical four chamber view (Fig. 5b). The absence of a ventriculoatrial shunt can also be confirmed by the lack of systolic turbulence in the right atrium (Fig. 5c).

It is generally accepted that infravalvar ventriculoatrial communications always have associated anomalies of the tricuspid valve adjacent to the defect. ${ }^{9-11}$ The following tricuspid valve anomalies had been identified and described ${ }^{1}{ }^{1012-17}$ : clefts or perforations of the septal leaflet; thickening and distortion of the septal leaflet; adherence of valve tissue to the margins of the defect; pouch like malformation caused by the presence of redundant valve tissue, and finally widening of, or incomplete attachment of, the tricuspid valve to the membranous component of the ventricular septum at the antero- 
medial commissure. Some of these anomalies are probably important in the pathogenesis of the shunt while others may only be associated anomalies. Some of these anomalies were demonstrated echo- graphically in all patients with a ventriculoatrial shunt and in a quarter of those without. The importance of these anomalies could not be determined echocardiographically. The pouch like mal-

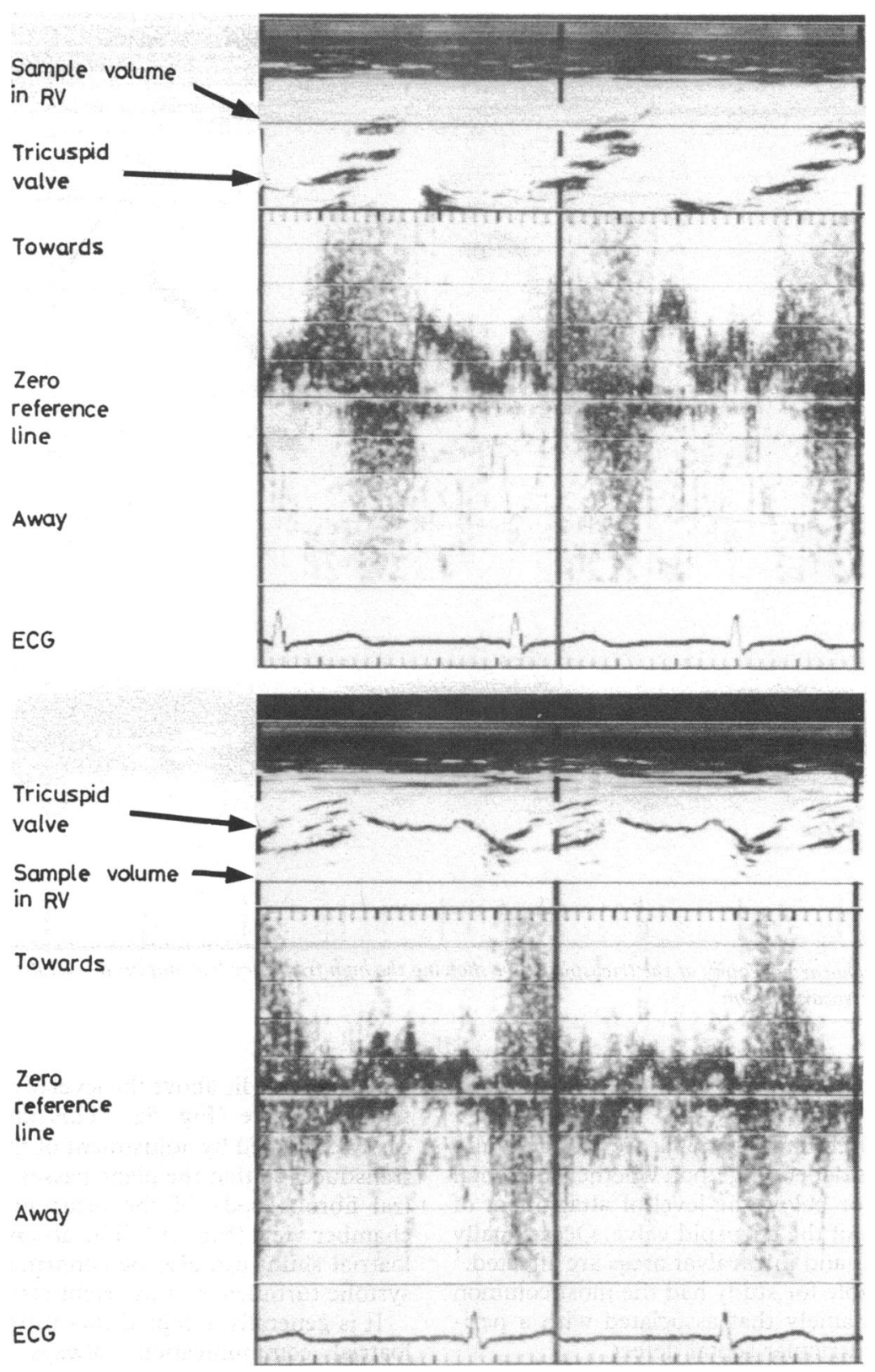

Fig. 4 Graphic display of Doppler echocardiography showing systolic turbulence in both right ventricle $(R V)$ and right atrium $(R A)$. ECG, electrocardiogram. 

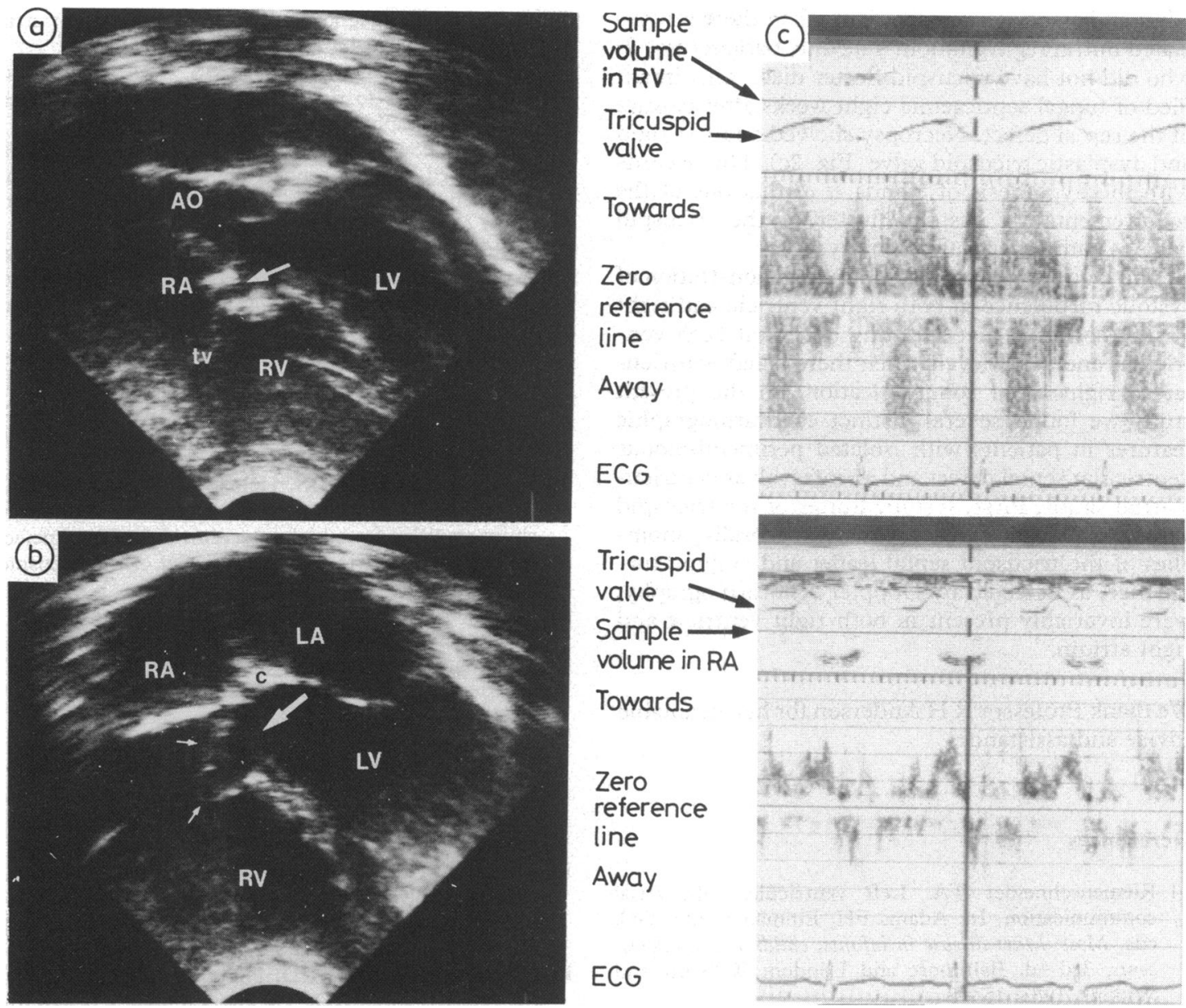

Fig. 5 (a) Malaligned subcostal four chamber view of cross sectional echocardiogram in two patients with interventricular shunts alone. This view gave a false impression of direct communication (white arrow) between the left ventricle and right atrium. (b) Apical four chamber view passing through the central fibrous body showing a perimembranous ventricular septal defect (thick white arrow) with pouch like malformation of redundant septal leaflet of the tricuspid valve (small white arrows). (c) Graphic display of Doppler echocardiogram showing systolic turbulence in the right ventricle but not in the right atrium. ECG, electrocardiogram. Other abbreviations are given in the legend to Fig. 1.

formation of the tricuspid septal leaflet seen by angiography resembles the so called aneurysm of the membranous septum. ${ }^{18}$ It may represent one of the features of the normal variations in tricuspid valve attachments to the membranous component of the ventricular septum. ${ }^{11}$ The adherence of tricuspid valve tissue to the margins of the defect may represent a mechanism of spontaneous closure. ${ }^{15} 18$ The tricuspid anomalies by themselves are not diagnostic of a ventriculoatrial shunt. When they are demonstrated in the presence of a perimembranous defect, however, an associated ventriculoatrial shunt should be suspected. Systolic turbulence should be sought in the right atrium in the vicinity of the anomaly.
The rare echocardiographic finding of systolic flutter of the tricuspid valve was of diagnostic value in cases of congenital infravalvar ventriculoatrial communication $^{23}$ The flutter was of high frequency and low amplitude. Grenadier et al, however, reported low frequency high amplitude oscillations of the tricuspid valve throughout systole in a 13 year old girl with an infravalvar ventriculoatrial communication and mitral regurgitation. ${ }^{5}$ In the present study, high frequency low amplitude systolic flutter of the tricuspid valve was demonstrated in five of the six patients with a ventriculoatrial shunt. It seems reasonable to suggest that the low frequency high amplitude tricuspid oscillations reported by Gren- 
adier and associates are a variant when there is associated mitral regurgitation. The only patient (case 2) who did not have tricuspid flutter died. This infant died of fungal septicaemia eight weeks after closure of the septal defect. Necropsy showed a rather rigid and dysplastic tricuspid valve (Fig. 2c). This accords with the hypothesis of Nanda et al that one of the requirements for systolic flutter of the tricuspid valve is sufficient local flexibility. ${ }^{2}$

The Doppler echocardiographic demonstration of systolic turbulence in both right ventricle and right atrium confirms that shunting occurs at both ventricular and atrial levels when there is left ventricular to right atrial communication. In the present study we found several distinct echocardiographic features in patients with isolated perimembranous ventricular septal defect and an infravalvar ventriculoatrial shunt. First, systolic flutter of the tricuspid valve was present in most patients. Secondly, anomalies of the tricuspid septal leaflet and systolic turbulence, as detected by Doppler echocardiography, were invariably present in both right ventricle and right atrium.

We thank Professor R H Anderson for his invaluable advice and assistance.

\section{References}

1 Riemenschneider TA. Left ventricular-right atrial communication. In: Adams FH, Emmanouilides GC, eds. Moss' heart disease in infants, children and adolescents. 3rd ed. Baltimore and London: Williams and Wilkins, 1983: 154-8.

2 Nanda NC, Gramiak R, Manning JA. Echocardiography of the tricuspid valve in congenital left ventricular-right atrial communication. Circulation 1975; 51: 268-72.

3 Mills P, McLaurin L, Smith C, Murray G, Craige E. Echocardiographic findings in left ventricular to right atrial shunts. Br Heart $\mathcal{F}$ 1977; 39: 594-7.

4 Marino P, Dander B, Salazzari GC, Perini GP, Poppi A. Echocardiographic diagnosis of congenital left ventricular-right atrial communication. Eur $\mathcal{f}$ Cardiol 1979; 9: 493-7.

5 Grenadier E, Shem-Tov A, Motro M, Palant A. Echo- cardiographic diagnosis of left ventricular-right atria communication. Am Heart $\mathcal{F}$ 1983; 106: 407-9.

6 Shanes JG, Levitsky S, Seyal MS, et al. Diagnosis of left ventricular to right atrial shunt utilizing contrast echocardiography. Am F Cardiol 1983; 52: 650.

7 Cross SW, Sagar KB, Paulsen WJH. Two-dimensional and pulsed Doppler echocardiographic diagnosis of an acquired left ventricular-right atrial communication. Am $\mathcal{F}$ Cardiol 1984; 53: 396-7.

8 Sutherland G, Godman MJ, Smallhorn JF, Guiterras $\mathrm{P}$, Anderson RH, Hunter S. Ventricular septal defects. Two dimensional echocardiographic and morphological correlations. Br Heart f 1982; 47: 316-28.

9 Perry EL, Burchell HB, Edwards JE. Cardiac clinics; congenital communication between the left ventricle and the right atrium: coexisting ventricular septal defect and double tricuspid orifice. Proceedings of the Staff Meetings of the Mayo Clinic 1949; 24: 198-206.

10 Stahlman M, Kaplan S, Helmsworth JA, Clark LC, Scott HW Jr. Syndrome of left ventricular-right atrial shunt resulting from high interventricular septal defect associated with defective septal leaflet of the tricuspid valve. Circulation 1955; 12: 813-8.

11 Rosenquist GC, Sweeney LJ. Normal variations in tricuspid valve attachments to the membranous ventricular septum: a clue to the etiology of left ventricular-to-right atrial communication. Am Heart $\mathcal{f}$ 1975; 89: 186-8.

12 Riemenschneider TA, Moss AJ. Left ventricular-right atrial communication. Am F Cardiol 1967; 19: 710-8.

13 Elliot LP, Gedgaudas E, Levy MJ, Edwards J. The roentgenologic findings in left ventricular-right atrial communication. $A \mathcal{F}$ 1965; 93: 304-14.

14 Chesler E, Korns ME, Edwards JE. Anomalies of the tricuspid valve, including pouches, resembling aneurysms of the membranous ventricular septum. $A m \mathcal{F}$ Cardiol 1968; 21: 661-8.

15 Freedom RM, White RD, Pieroni DR, Varghese PJ, Krovetz LJ, Rowe RD. The natural history of the socalled aneurysm of the membranous ventricular septum in childhood. Circulation 1974; 49: 375-84.

16 Tandon R, Edwards JE. Aneurysmlike formations in relation to membranous ventricular septum. Circulation 1973; 47: 1089-97.

17 Burrows PE, Fellows KE, Keane JF. Cineangiography of the perimembranous ventricular septal defect with left ventricular-right atrial shunt. $\mathcal{F} \mathrm{Am}$ Coll Cardiol 1983; 1: 1129-34.

18 Anderson RH, Lenox CC, Zuberbuhler JR. Mechanisms of closure of perimembranous ventricular septal defect. Am f Cardiol 1983; 52: 341-5. 